Мср Дина Петровић*

Докторанд

Филолошког факултета

Универзитета у Београду
371.671:811

https://doi.org/10.18485/melissa.2018.17.1.ch15

Прегледни рад

Примљен: 17.07.2018

Прихваћен: 11.09.2018.

\title{
ДИГИТАЛНИ АЛАТИ У ПРОЦЕСУ УСВАЈАЊА СТРАНОГ ЈЕЗИКА
}

\section{Сажетак}

Циљ овог рада је да се на основу истраживачких студија, у којима је утврђена ефикасност примене дигиталних алата, укаже на њихове потенцијале у оквиру кључних области учења страних језика: граматике, вокабулара, говора и изговора, читања, писања и слушања. Сагласно томе у главном делу рада дат је систематичан приказ новијих истраживања у којима је, експрименталним путем, потврђена већа успешност у учењу садржаја из области страних језика уз помоћ дигиталних технологија. У закључном делу рада се констатује да савремени дигитални алати, посебно рачунарски системи, наменски дизајнирани софтвери и апликације имају високе потенцијале у усвајању страних језика.

Кључне речи: нова култура учења, дигитални алати, страни језици, учење, истраживање

\section{1. Увод}

Примена дигиталних медија условила је значајне промене у учењу страних језика, развила нове облике и методе учења, као и другачије приступе развоју језичких компетенција. Појава интернета и савремених дигиталних алата омогућила је стицање знања из различитих извора, као и пренос информација електронским путем, што је битно изменило традиционалну културу учења, укључујући и учење страних језика. Сходно томе, дошло је до битних промена у образовању будућих филолога, а савремене дигиталне технологије

Филолошки факултет, Студентски трг 3, 11000 Београд

dina.petrovic@yahoo.com 
постале су саставни део формалног плана и програма у развијеним земљама. На простору Европе, интеграција дигиталних технологија у процес образовања на високошколским институцијама подржана је у званичним документима које је донела Европска комисија (European Commission, 2014). У нашој земљи потреба за све већим коришћењем дигиталних технологија у процесу образовања дефинисана је стратешким документом којим се планира развој система образовања до 2020. године (Strategija razvoja obrazovanja u Srbiji do 2020. godine).

Све већа примена технологија новије генерације у учењу страних језика изазвала је потребу за истраживањем различитих аспеката савремених дигиталних алата у процесу усвајања страног језика. Потреба за проучавањем неопходна је како са аспекта теоријског утемељења, тако и у смислу утврђивања потенцијала и предности које учење страних језика чине успешнијим. У том контексту, основни циљ овог рада је да се размотри релевантна литература о примени дигиталних алата у у областима које су кључне за усвајање страних језика.

\section{2. Дигитални алати у култури учења страних језика}

Имплеметација дигиталних технологија условила је промене у образовању које се означавају као „нова култура учења“, а односе се на мењање садржаја, извора, облика и начина стицања знања. Развој нове културе учења детаљније описује Родек (Rodek, 2013), наводећи два кључна узрока: потребе савременог друштва и карактеристике младих данашњице. Према наводима овог аутора, за развој друштва, поред традиционалног приступа учењу, неопходно је развијати и „иновативно и антиципацијско учење, које се заснива на преструктуирању, редефинисању и трансформацији“ (Rodek, 2013:13). У том контексту, циљ учења више није стицање и меморисање што већег броја информација, већ анализа, селекција и функционалност, у циљу промене структуре знања. Сходно томе, наставници страних језика и њихови студенти морају препознати да учење у дигиталној ери захтева нове компетенције које укључују критичко размишљање, решавање проблема, сарадњу, учешће и дистрибуцију у дигиталним 
окружењима (Black, 2006; Gee, 2006). Генерације данашњих ученика и студената расле су заједно са дигиталним технологијама, интернетом и мобилним телефонима. Њихово схватање учења и знања битно је измењено у односу на традиционалну парадигму учења у којој су наставници, креда итабла били основни извори стицања знања. Развој интернета и дигиталних алата новије генерације нуди нове изворе знања, који традиционално учење све више замењују електронским учењем. У складу са тим, током последњих двадесет година интернет заузима посебно место у креирању медијског окружења за учење, а у литературу се уводе нови термини као што је: онлајн учење (online learning), е-учење (e-learning), учење утемељено на веб-у (web based learning), a у новије време и учење путем мобилних уређаја (m-learning). Овој групи припадају и различити облици учења на даљину (distance learning), као и примена разноврсних дигиталних алата за пренос знања. Током последњих година све је значајније мобилно учење, засновано на преносивим уређајима попут мобилних телефона, таблета, ПДА уређаја и лаптоп рачунара, који се сматрају технологијом будућности у образовању (Uzunboylu, Genc, 2017; Ally, Prieto-Blázquez, 2014).

Нема сумње да нове медијске технологије отварају нове перспективе учења, укључујући и учење страних језика, што потврђују резултати већег броја истраживања (Chun, Kern, Smith, 2016; Farr, Murray, 2016). Примена дигиталних алата уноси битне промене у путевима стицања знања, посматрано како са техничког, тако и са педагошког аспекта (Dementiev, Burulko, Suvorkova, 2015).

Са развојем савремених технологија влада све веће интересовање аутора за проучавање потенцијала дигиталних алата у усвајању страног језика. Већи број истраживања усмерен је ка проучавању могућности које имају нови дигитални алати у односу на развој кључних области језика и језичких вештина, као што су граматика, читање, писање, изговор и култура (Strickland, Grantham O’Brien, 2013). Данас је познато да се у учењу страних језика може користити већи број разноврсних дигиталних алата, који се разликују у односу на њихове техничке карактеристике и конкретну намену. Њихов заједнички циљ је да пруже подршку студентима у учењу страних језика у домену читања, писања, слушања и говора. 
Број нових дигиталних алата који се могу користити у учењу страних језика са годинама убрзано расте, а како је реч о разноврсним алатима са различитим наменама, постоји потреба за њиховом класификацијом у циљу јаснијег увида у могућности њихове примене. Дигитални алати који се користе у учењу страних језика, према наводима Голонке и сарадника (Golonka, Bowles, Frank, Richardson i Freynik, 2014: 72-76 ) могу се поделити у следеће категорије:

- Технологије базиране на раду у учионици (системи за управљање курсевима, интерактивне табле, ePortfolio);

- Технологије намењене индивидуалном учењу (corpus, електронски речници, електронске анотације, интелигентни туторски системи, системи за проверу граматике, програми за аутоматско препознавање говора и изговора);

- Мрежни системи (виртуелна окружења и игре, чет, социјалне мреже, блог, интернет форуми, вики);

- Мобилни и преносиви уређаји - разни таблети, паметни телефони и апликације.

Примена дигиталних алата у учењу страних језика има своје предности и ограничења. Предности се односе на већу аутономију студената у учењу, могућност понављања жељених садржаја, постојање непосредне и детаљне повратне информације у вези са напредовањем и грешкама, доступност и флексибилност, нелинеарно учење, повећану мотивацију, мање фрустрације и нове врсте вежби. С друге стране, ограничења се односе на недостатак адекватне опреме и обученог кадра, цену појединих специјализованих софтвера, као и отпор према технолошким иновацијама (Kilickaya, 2007). Поред познавања предности и недостатака, веома је важно питање селекције и усклађивања одређеног типа дигиталних алата са циљевима развоја језичких компетенција.

\section{3. Преглед истраживања дигиталних алата у кључним областима учења страних језика}

У намери да се пружи бољи увид у потенцијале и ефикасност дигиталних технологија у одређеним областима учења страних 
језика, у овом раду дата је систематизација и преглед релевантних истраживања. Како се у литератури може наћи већи број истраживања која се баве овом тематиком, први корак био је избор релевантних истраживачких радова. За адекватан одабир радова коришћена су два критеријума: (1) да је у истраживањима утврђена ефикасност дигиталних алата у одређеној области учења страних језика; (2) да су истраживања новијег датума. Други критеријум одабран је из два разлога: први је интензивни развој нових технологија и појављивање дигиталних алата нове генерације; други је обухваћеност истраживања у већ постојећим студијама Стоквела (Stockwell, 2007) и Голонке и сарадника (Golonka, Bowles, Frank, Richardson i Freynik, 2014) у којима је дат преглед истраживачких радова о примени дигиталних алата у развоју језичких компетенција до 2013. године. У складу са тим, за потребе овог рада, изабрани су истраживачки радови који нису обухваћени овим студијама.

Након одабира радова извршена је систематизација и дат преглед дигиталних алата који су показали високу ефикасност у кључним областима учења страних језика: граматике, вокабулара, изговора, читања, писања, слушања и говора.

\section{1 Дигитални алати као подршка учењу граматике}

У области учења граматике страних језика користе се разне апликације за размену материјала и комуникацију, затим апликације које помажу у креирању интерактивних тестова и вежби - питања са више понуђених одговора, промењен ред речи у реченици, укрштенице, повезивање сличности и разлика, вежбе за допуњавање реченица и друге разне онлајн вежбе (нпр. Hot potato, Kahoot). Учењу граматичких садржаја подршку пружају дигитални речници (Longman digital dictonary), као и разни специјализовани софтвери. Студије у којима се истражује примена дигиталних алата у учењу граматике углавном се фокусирају на подучавање нових граматичких израза или побољшање синтактичке тачности или сложености.

У учењу граматичких садржаја веома су популарни системи за помоћ у учењу језика (CALL - Computer-assisted language learning, 
односно системи за учење страних језика уз помоћ рачунара), који нуде атрактивне могућности за вежбање граматички правилног говора у комбинацији са технологијом за аутоматско препознавање говора. У овим системима се користи посебна технологија за обраду одговора студената и за откривање грешака, тако да се кроз повратне информације одмах могу извршити корекције. У испитивању о ефикасности овог система у учењу холандске граматике, утврђено је да су студенти побољшали своја знања из циљних граматичких подручја на основу чега је закључено да је систем био успешан (de Vries et al., 2015). Последњих година велика пажња посвећује се дизајнирању посебних апликација које су намењене бољем усвајању граматике страног језика. За потребе своје докторске дисертације Ма (Ma, 2016) је развила апликацију која пружа експлицитне инструкције о граматичким обрасцима (Pat gram). Да би се обезбедили додатни докази о ефикасности ове апликације урађено је и истраживање са учесницима студије у коме је испитивана њихова перцепција процеса учења путем апликације. Резултати студије су показали да примењена апликација има високе потенцијале за пружање делотворних експлицитних инструкција о граматичким обрасцима, да омогућава брзу идентификацију грешака и успешне корекције на основу датих упутстава.

Развој мобилних технологија омогућио је све популарније мобилно учење, па се у складу са тим појављују мобилне апликације наменски дизајниране за учење одређених граматичких јединица страних језика. Истраживање реализовано на америчком универзитету Мидвестерн пружа податке о примени мобилне апликације која је дизајнирана као низ граматичких вежби (Grammar Clinic) које имају за циљ проналажење грешака на нивоу реченице и могућност њихове корекције. Апликација која је примењивана током једног семестра дала је веома задовољавајуће резултате: студенти који су користили апликацију су показали већу успешност на граматичком пост-тесту и значајно смањење броја грешака (Li, Hegelheimer, 2013).

У учењу граматичких садржаја велики потенцијал имају наменски дизајниране рачунарске игре. Наиме, у истраживањима је потврђено да рачунарске игре, које су посебно креиране за учење граматике, поред бољих резултата у учењу утичу и на повећање мотивације студената и смањење фрустрација које се могу јавити 
на часовима намењеним граматичким јединицама (Raftery, Santos, 2015). Примена рачунарских игара обезбеђује учење граматичких правила на интересантан начин, кроз брзо уочавање грешака и могућности за корекције, што их чини вредним алатима за наставнике страних језика.

\section{2 Дигитални алати у усвајању и ширењу вокабулара}

Један од важних корака у учењу страних језика је усвајање и ширење вокабулара, као основе за разумевање значења речи, текстова и говора. Дигиталне технологије имају високе потенцијале у развоју вокабулара, пре свега због великог броја дигиталних алата који се могу користити у ове сврхе. Међу њима се издвајају специјално дизајниране апликације које укључују мултимедијалне елементе, електронски речници и онлајн апликације за превођење, мобилне апликације, наменски дизајнирани алати за одређене лекције, интерактивне игре, сајтови за учење нових речи, као и велики број текстова, блогова и влогова (видео блогова).

Да се добра пракса у развоју вокабулара може побољшати кроз специјално дизајниране мултимедијалне апликације показала је експериментална студија која је реализована у Ирану у циљу испитивања ефеката примене рачунарског програма за учење нових речи (Maftoon, Hamidi, Najafi Sarem, 2012). У овој студији истраживањем је обухваћено 40 ученика средњих школа који уче страни језик. У експерименталној групи примењен је рачунарски програм (VTS.S), док је контролна група учила речи на конвенционални начин, помоћу речника. Резултати студије су показали да је експериментална група на завршном тесту постигла боље резултате у усвајању нових речи у односу на контролну групу. Слично томе, резултати студије која је спроведена на Тајвану са студентима који студирају енглески као страни језик потврђује предности коришћења аудио снимака у ширењу вокабулара (Webb, C-S Chang, 2015). Налази истраживања показују да су студенти који су користили аудио снимке научили већи број речи и знатно проширили вокабулар, што су показали и резултати тестова. 
Сматра се да карактеристике дигиталних алата попут интерактивности и мултумедијалности могу бити значајне у ширењу вокабулара. У прилог томе говоре резултати студије у којој су испитивани ефекти интерактивног и симултаног приказа визуелних и вербалних, мултимедијалних информација. У студији је учествовало 82 учесника чије је знање енглеског језика на нижим нивоима. Једна група студената је користила интерактивне приказе речи, па су учесници експеримента у овој групи могли да бирају врсту мултимедијалне информације за сваку реч. Друга група студената није била у могућности да бира редослед и начин приказа речи, већ су се оне смењивале према раније утврђеном редоследу и биле објашњене само сликовито. Тестирање спроведено на крају истраживања је показало да су студенти, који су могли да бирају начин приказа, увек бирали мултимедијалне садржаје и као резултат имали знатно бољу успешност на завршном тесту разумевања вокабулара. У складу са тим констатовано је да представљање вербалних и визуелних информација истовремено смањује когнитивно оптерећење и резултира бољим учењем (Türk, Erçetin, 2014).

Рачунарске игре и виртуелна реалност могу обезбедити окружење за веома успешно усвајање нових речи, што је током последњих година потврђено у већем броју студија. Примера ради, у једној експерименталној студији је доказано да се постиже виши ниво разумевања вокабулара када се он усваја кроз игру са виртуелном реалношћу, у односу на конвенционалне начине рада у учионици. Резултати студије указују да се кроз игру активно учи значење нових речи и да се подстиче боље разумевање (Zheng, Bischoff, Gilliland, 2015). У рачунарској игри усвајање нових речи углавном није само себи сврха, већ се јавља из потребе да се реше проблемске ситуације, које без разумевања речи не би могле да буду превазиђене. Многе игре са виртуелном реалношћу захтевају високе нивое когнитивних способности и широк дијапазон вештина и разумевања да би биле одигране. Учење значења нових речи кроз кретање у виртуелној реалности омогућава студентима развој различитих стратегија учења, другачијих у односу на оне који се користе у конвенционалном приступу. Да би се разумео утицај различитих стратегија на исходе учења 
у виртуелном свету, развијен је аналитички метод визуализације како би се испитали различити стилови учења ученика. Примена овог метода је показала да успешнији ученици користе другачије стилове учења речи од оних мање успешних (Hsiao et al., 2017). Оваква истраживања су од посебног значаја јер у будућности могу допринети развоју још квалитетнијих виртуелних игара намењених учењу вокабулара.

Мобилно учење страног језика представља приступ заснован на употреби све популарнијих мобилних уређаја, као што су мобилни телефони и таблети. Широка функционалност мобилних телефона донела је више платформи за учење вокабулара. У оквиру мобилне платформе за потребе учења вокабулара, најчешће се користе:

(1) онлајн речници за помоћ у разумевању значења речи,

(2) видео садржаји за говор и учење изговора нових речи и

(3) друштвене мреже, које се могу користити као средство за вежбање новонасталог вокабулара у писаној форми (Mohd Asraf, Supian, 2017: 16). Мобилни уређаји су веома блиски младима, те је коришћење мобилних платформи сасвим примерен начин за учење нових речи у страним језицима. Путем мобилних уређаја студенти са већим самопоуздањем користе нове речи које су научили, а кроз употребу развијају и боље разумевање значења.

\section{3 Дигитални алати за вежбање изговора и говора}

у литератури се за потребе побољшања изговора у учењу страног језика, осим широко коришћених дигитализованих аудио снимака, најчешће помињу системи за аутоматско препознавање говора (ASR - automatic speech recognition), који се могу укључити у специјално дизајниране апликације са мултимедијалним елементима, мобилне апликације, наменски дизајниране алате за наставне лекције, интерактивне игре и др. Развој језичких компетенција обухвата правилан изговор који поред познавања граматике и вокабулара има кључни значај. Наиме, познавање речи само по себи није довољно, јер уколико је изговор неправилан, нема адекватног споразумевања у комуникацији. Добар изговор речи може да обе- 
збеди бољу комуникацију и лакше разумевање са матерњим говорницима, или другима који говоре одређени страни језик. Премда је позната важност изговора у учењу страних језика, ипак се овој вештини у пракси не придаје довољан значај од стране наставника (Nair, Krishnasamy, de Mello, 2006).

Потпуно је очекивано да студенти који вежбају уз аудио снимке говорника матерњег језика постижу боље резултате и правилнији изговор речи, што је потврђено истраживањима (Luo, 2016). У истраживачкој студији која је користила програм са аутоматским препознавањем изговора, као и писани и визуелно представљени садржај, утврђени су бенефити коришћења оваквих програма (Liakin, Cardoso, Liakina, 2015). Наиме, на узорку од 42 студента утврђено је да примена ASR апликације на мобилним уређајима доприноси правилнијем изговору страних речи. Резултати студије потврђују став о значају посебно дизајнираних софтвера за изговор страних речи који доприносе већој успешности у домену изговора.

ASR системи који су уграђени у веб алате пружају читав низ могућности за вежбање изговора, што може бити значајно за превазилажење потенцијалних проблема који се могу јавити у усменој комуникацији.Наиме,овисистеми(нпр.GoogleWebSpeech)транскрибују изговорене речи, па је могуће на основу транскрипције уочити грешке у изговору и радити на побољшању. На основу истраживања, може се констатовати да ASR служи као средство за побољшање аутономије у учењу, које помаже студентима да побољшају нејасан изговор и да што правилније изговарају научене речи (Wallace, 2016).

Могућности дигиталних алата још увек нису у потпуности истражене, јер се стално јављају инвентивни приступи о њиховој примени у учењу правилног говора и изговора. У том контексту интересантни су резултати студије о коришћењу музичких апликација за побољшање изговора (Sundberg, Cardoso, 2015). Резултати студије показали су да се музичке апликације могу користити за вежбање изговора, али да, за разлику од наменски дизајнираних, имају и нека ограничења: не подстичу слободну форму говора и не пружају повратне информације студентима. Ипак, без обзира на постојећа ограничења, музичке апликације могу бити корисне у учењу изговора, посебно због позитивног утицаја на мотивацију студената. 
За вежбање вештине говора и изговора, с обзиром на њихову повезаност, се могу користити исти или слични дигитални алати. Као типичан пример за то може се издвојити podcasting - дигитална датотека са аудио или аудио-видео записима која се дистрибуира путем интернета. Наставници страних језика користе podcasting као средство за испоруку едукативних материјала и подстицање учења изван зидова учионице. Истраживање ефеката podcasting-а на учење страног језика је доказано посебно у домену побољшања говорних вештина (Farangi et al., 2015). Укључивање овог дигиталног алата у процес учења страног језика дало је изузетне резултате, те су све учесталији предлози за његову имплементацију у званични наставни програм.

Компјутерски подржано учење језика може допринети побољшању говорних вештина на страном језику, посебно уколико се користе различити туторијали за вежбање говора и изговора. Туторијали се сматрају инвентивним средствима за вежбање правилног изговора, нарочито када се страни језик учи у земљи у којој су културолошки и језички системи потпуно другачији. У циљу постизања што бољих резултата на пољу говорних вештина јавља се и могућност интеграције дигиталних алата. Примера ради, могу се примењивати Facebook - као средство за асинхрону онлајн дискусију, као и Skype - за синхрону онлајн дискусију студената. Интеграција ова два дигитална алата даје добре резултате у развоју говорних вештина и може допринети подстицању развоја способности говора у смислу тачности и сложености (Yen, Hou, Chang, 2015).

\section{4 Дигитални алати за побољшање читања и писања}

Нове технологије у комбинацији са традиционално оријентисаним приступом могу побољшати вештине говора, слушања, читања и писања (Blake, 2016). Конкретније, када је реч о читању и писању, истраживање спроведено у Палестини на Универзитету Хеброн са 104 студента енглеског језика, потврдило је бенефите употребе дигиталних технологија у учењу. Поред успешнијег учења страног језика, примена дигиталних алата доприноси развоју мотивације, повећању самопоуздања, као и смањењу анксиозности, 
која се јавља у традиционалном начину рада (Farrah, Tushyeh, 2010). У истом истраживању се констатује да дигиталне технологије могу да учине учење страног језика пријатним, занимљивим и узбудљивим. Резултати ове студије указују да коришћење дигиталних технологија побољшава способности читања и писања студената енглеског језика.

Осим дигиталних технологија, које генерално имају бенефите на учење страних језика, као што су специјализовани софтвери за организовање наставе, посебно развијене апликације, мултимедијални садржаји и слично, добре резултате, конкретно у домену вештине читања са разумевањем, даје рад на тексту са анотацијама (енг. Glosses). У једној од студија је утврђено да текстови са анотацијама на матерњем језику битно утичу на разумевање прочитаног текста (Taylor, 2014).

За тачност у писању посебан значај имају вежбе које промовишу колаборативно писање помоћу онлајн сервиса. Колаборативно писање подразумева активности у којима студенти заједнички преговарају и доносе одлуке о тексту који ће писати, што у крајњој инстанци доводи до заједничке одговорности за тачност и квалитет написаног текста (Storch, 2013: 3). Истраживања ефеката колаборативног писања уз употребу интернет алата (нпр. Google Docs) показују да је група која се бавила колаборативним писањем на вебу показала статистички значајне разлике средњих вредности у односу на групе које нису користили онлајн алате (Bikowski, Vithanage, 2016). У истом истраживању утврђено је да интернет алати омогућавају колаборацију на нивоу који није могуће остварити приликом класичног писања на папиру или рада у процесорима текста. У складу са тим, овакав облик вежбања писања препоручује се у раду, посебно са студентима завршних година студија (Bikowski, Vithanage, 2016).

\section{5 Дигитални алати намењени развоју вештине слушања}

Дигиталне технологије могу се користити за побољшање успешности учења страних језика, али нису подједнако применљиве за развој свих језичких вештина. Према наводима аутора (ĐukićMirzayantz, 2011), рачунар је врло користан за учење граматике и 
вокабулара, за развијање вештине читања и писања, али зато мање погодан за унапређивање вештине слушања и говора. Међутим, с обзиром на развој рачунарских система и појаву све већег броја софтверских алата, последњих година појављују се апликације које доприносе развоју вештине слушања. Све присутнија дигитализација аудио-визуелних материјала доприноси све већој употреби разноврсних апликација које се могу примењивати у вежбама слушања.

Сматра се да интеграција онлајн аудио-визуелних материјала може имати мерљив утицај на развој слушања са разумевањем приликом учења као страног језика (Becker, Sturm, 2017). Резултати истраживања су показали да иако су две групе започеле студију на готово истом нивоу способности слушања, експериментална група је имала боље резултате на завршном тесту. Иако разлика у резултатима тестова није била значајна, ова студија представља прелиминарну индикацију да активности које користе онлајн аудио-визуелне материјале могу имати позитиван утицај на развој способности слушања.

У другој студији реализованој на Тајвану, проучавана је употребна вредност титлова, као дигиталних алата, у процесу јачања вештина слушања (Yang, 2014). Титлови су били припремљени унапред, плански, са циљем да допринесу бољем разумевању садржаја аудио-визуелних материјала. У истраживању су коришћени титлови на два језика - на матерњем језику слушаоца, као и на језику који се учи, односно на коме је приказани аудио-визуелни материјал. Такво двоструко кодирање представља битну подршку у слушању и разумевању текста, јер омогућава да се повежу вештине читања и слушања, односно да се постојећи ниво вештине читања користи као помоћ за јачање вештине слушања. Резултати истраживања указују на позитивне ефекте коришћења титлова у развоју вештине слушања.

\section{4. Закључна разматрања}

Примена савремених дигиталних технологија у усвајању страних језика довела је до промена у путевима сазнања и развила нову културу учења. Дигитални алати са својим техничким карактеристикама, међу којима се издвајају мултимедијалност и интерактивност, 
имају велике потенцијале за успешније усвајање садржаја у кључним областима страних језика. Сагласно томе у релевантној литератури све су присутнија истраживања о могућностима употребе дигиталних алата у учењу страних језика. За потребе овог рада извршена је селекција истраживачких студија у којима је утврђено да примена дигиталних алата доприноси ефикаснијем усвајању страног језика у области граматике, вокабулара, говора и изговора, читања, писања и слушања.

На основу приказа и анализе одабраних истраживања може се закључити да постоје велики потенцијали дигиталних алата у учењу кључних вештина страних језика. Висока функционалност савремених рачунарских система отвара могућности за примену дигиталних алата у развоју различитих компетенција, тако да је тешко поједине дигиталне алате везати за само за одређену област. У том контексту може се констатовати да нису сви дигитални алати подједнако ефикасни у свим областима учења страног језика. Међутим, са развојем технологија нове генерације, поједини дигитални алати могу се користити успешно у више области. Међу њима се издвајају посебно дизајнирани софтвери и апликације које пружају могућности за остваривање веће успешности у учењу граматике, вокабулара, читања и писања или говора. Сходно томе, важно је потенцирати питање избора адекватних дигиталних алата који су примерени за остваривање циљева учења страних језика у развоју компетенције. Важну улогу у том процесу имају наставници, односно предавачи страних језика, од којих се очекује висока компетентност у селекцији и начину примене дигиталних алата. У том контексту потребно је размишљати о променама у образовању будућих наставника страних језика у правцу бољег информисања о потенцијалима савремених дигиталних алата и начинима примене у складу са циљевима учења.

Допринос овог рада огледа се у томе што даје систематизацију и преглед истраживања ефикасности примене дигиталних алата у кључним областима учења страног језика, што може бити од значаја предавачима приликом селекције и избора адекватних средстава у настави и учењу. Међутим, с обзиром на релативно мали број приказаних истраживања, што је свакако ограничење овог рада, закључке 
не треба генерализовати. У складу са тим, може се констатовати да овај рад може чинити полазну основу за будућа истраживања о примени дигиталних алата у кључним областима развоја језичких вештина.

\section{Извори и литература}

Ally, Mohamed, and Josep Prieto-Blázquez. „What is the future of mobile learning in education?" International Journal of Educational Technology in Higher Education, 11(1) (2014): 142-151.

Becker, Shannon R., and Jessica L. Sturm. „Effects of Audiovisual Media on L2 Listening Comprehension: A Preliminary Study in French". Calico journal, 34(2) (2017): 147177.

Bikowski, Dawn, and Ramyadarshanie Vithanage. „Effects of web-based Collaborative writing on individual L2 writing development". Language Learning \& Technology, 20(1) (2016): 79-99.

Black, Rebecca. „Digital design: English language learners and reader reviews in online fiction". M. Knobel, C. Lankshear (Eds.), A new literacies sampler. New York: Peter Lang Publishing, 2006. 115-136.

Blake, Robert. „Technology and the four skills”. Language Learning \& Technology, 20(2) (2016): 129-142.

Chun, Dorothy, Richard Kern, and Bryan Smith. „Technology in Language Use, Language Teaching, and Language Learning". The Modern Language Journal, 100 (2016): 64-80.

Dementiev, Yury, Lev Burulko, and Elena Suvorkova. „Pedagogical Aspects of Applied Software Packages and Computer Technologies Use in Students Education". Procedia - Social and Behavioral Sciences, 206 (2015): 289-294.

Đukić-Mirzayantz, Marina. Učenje jezika pomoću računara u praksi. Teme, XXXV(3) (2011): 859-873.

European Commission. New Modes of Learning and Teaching in Higher Education. Luxembourg: European Union, 2014.

Farangi, Mohamad Reza, Hassan Nejadghanbar, Fatemeh Askary, Islamic Azad, and Atefeh Ghorbani. ,'The Effects of Podcasting on EFL Upper-Intermediate Learners' Speaking Skills". CALL-EJ, 16(2) (2015): 1-18.

Farr, Fiona, and Liam Murray. The Routledge Handbook of Language Learning and Technology. Abingdon: Routledge, 2016.

Gee, James Paul. „Pleasure, learning, video games, and life: The projective stance”. M. Knobel, C. Lankshear (Eds.), A new literacies sampler. New York: Peter Lang Publishing, 2006. 95-114. 
Golonka, Ewa M., Anita R. Bowles, Victor M. Frank, Dorna L. Richardson, and Suzanne Freynik. „Technologies for foreign language learning: a review of technology types and their effectiveness". Computer Assisted Language Learning, 27(1) (2014): 70105.

Kılıçkaya, Ferit. „The Effect of Computer-Assisted Language Learning on Turkish Learners' Achievement on the TOEFL Exam". Teaching English with Technology: A Journal for Teachers of English, 7(1) (2007): 1-25.

Li, Zhi, and Volker Hegelheimer. „Mobile-assisted grammar exercises: Effects on selfediting in L2 writing". Language Learning \& Technology, 17(3) (2013): 135-156.

Liakin, Denis, Walcir Cardoso, and Natallia Liakina. „Learning L2 pronunciation with a mobile speech recognizer: French /y/". Calico journal, 32(1) (2015): 1-25.

Luo, Beate. „Evaluating a computer-assisted pronunciation training (CAPT) technique for efficient classroom instruction". Computer Assisted Language Learning, 29(3) (2016): 451-476.

Ma, Hong. Developing and evaluating a pattern grammar inspired CALL tool: PAT GRAM. Graduate Theses and Dissertations: 15072. (2016). Retrived from: http://lib. dr.iastate.edu/etd/15072

Maftoon, Parviz, Hadi Hamidi, and Saeid Najafi Sarem. „The effects of call on vocabulary learning: a case of Iranian intermediate EFL learners". BRAIN, Broad Research in Artificial Intelligence and Neuroscience, 3(4), (2012): 19-30.

Mohd Asraf, Ratnawati, and Nadya Supian. „Metacognition and Mobile-Assisted Vocabulary Learning". Arab World English Journal, 8(2), (2017): 16-35.

Nair, Ramesh, Rajasegaran Krishnasamy, and Geraldine de Mello. „Rethinking the teaching of pronunciation in the ESL classroom". The English Teacher, XXXV, (2006): 27-40.

Raftery, Brian, and Jennifer Santos. „Grammar Games: A Case for Instructionist Game Models to Enhance Grammar Awareness and Accuracy". Journal of Instructional Research, 4, (2015): 142-147.

Rennie, Frank, and Tara Morrison. E-Learning and Social Networking Handbook: Resources for Higher Education. Abingdon: Routledge, 2013.

Rodek, Stjepan. „Novi mediji i nova kultura učenja”. Napredak, 152(1), (2011): 9-28.

Stockwell, Glenn. „A review of technology choice for teaching language skills and areas in the CALL literature". ReCALL, 19(2), (2007): 105-120.

Storch, Neomy. Collaborative writing in L2 classrooms. Bristol, UK: Multilingual Matters, 2013.

Strategija razvoja obrazovanja u Srbiji do 2020. godine. Službeni glasnik Republike Srbije br. 107/2012.

Strickland, Brandee Marie, and Mary G O'Brien. A Review of the Literature on Technology in Second and Foreign Language Learning. Caglary: The Language Research Centre (LRC) at the University of Calgary, 2013.

Sundberg, Ross, and Walcir Cardoso. „A musical application to aid second language learners' development of pronunciation features". Jan Volín (ed.), EPIP4 4 th 
International Conference on English Pronunciation: Issues \& Practices, Prague: Institute of Phonetics. 2015. 135-138.

Taylor, Alan. „Glossing frequency and $L 2$ reading comprehension: the influence of CALL glossing". Calico journal, 31(3), (2014): 374-389.

Türk, Emine, and Gülcan Erçetin. „Effects of interactive versus simultaneous display of multimedia glosses on L2 reading comprehension and incidental vocabulary learning". Computer Assisted Language Learning, 27(1), (2014): 1-25.

Farrah, Mohammed, and Hanna Tushyeh. „Enhancing the English Reading and Writing Skills of Palestinian English Majors by Using CALL". Hebron University Research Journal, 5(2), (2010): 259-282.

Uzunboylu, Huseyin, and Zeynep Genc. „Analysis of Documents Published in Scopus Database on Foreign Language Learning Through Mobile Learning: A Content Analysis". Profile: Issues in Teachers' Professional Development, 19(1), (2017): 99107.

Wallace, Lara. „Using Google web speech as a springboard for identifying personal pronunciation problems". J. Levis, H. Le, I. Lucic, E. Simpson, S. Vo (Eds). Proceedings of the 7th Pronunciation in Second Language Learning and Teaching Conference. Ames, IA: lowa State University. 2016. 180-186.

Yang, Hui-Yu. „The Effects of Advance Organizers and Subtitles on EFL Learners' Listening Comprehension Skills". Calico journal, 31(3), (2014): 345-373.

Yen, Yen-Chen, Huei-Tse Hou, and Kuo En Chang. „Applying role-playing strategy to enhance learners' writing and speaking skills in EFL courses using Facebook and Skype as learning tools: a case study in Taiwan". Computer Assisted Language Learning, 28(5), (2015): 383-406. 


\title{
Dina Petrović
}

PhD student, Faculty of Philology, University of Belgrade

\section{DIGITAL TOOLS IN FOREIGN LANGUAGE ACQUISITION}

\begin{abstract}
Summary
On the basis of research studies which confirmed the efficiency of digital tools, it is the aim of this paper to point to the potentials of digital tools in fundamental fields of foreign language learning/acquisition: grammar, vocabulary, speech and pronunciation, reading, writing and listening. Accordingly, the main part of the paper provides one with a systematic overview of recent research studies which have experimentally ascertained that foreign language contents are more successfully mastered with the help of digital technologies. In the concluding part of the paper it is established that modern digital tools, especially computer systems, intentionally designed software and applications have great potentials in the process of acquiring foreign languages.
\end{abstract}

Key words: new learning culture, digital tools, foreign languages, learning, research 